\title{
Phosphoric Acid-doped SDF-F/poly(VI-co-MPS)/PTFE Membrane for a High Temperature Proton Exchange Membrane Fuel Cell
}

\author{
Jongwon Lee, Cheol-Woo Yi, ${ }^{\dagger, *}$ and Keon Kim* \\ Department of Chemistry, Korea University, Seoul 136-701, Korea. *E-mail: kkim@korea.ac.kr \\ 'Department of Chemistry and Institute of Basic Science, Sungshin Women's University, Seoul 136-742, Korea \\ E-mail: cheolwoo@sungshin.ac.kr \\ Received December 12, 2010, Accepted April 16, 2011
}

\begin{abstract}
Sulfonated poly(fluorinated arylene ether)s (SDF-F)/poly[( $N$-vinylimidazole)-co-(3-methacryloxypropyl-trimethoxysilane)] (poly(VI-co-MPS))/poly(tetrafluoroethylene) (PTFE) is prepared for a high temperature proton exchange membrane fuel cell (PEMFC). The reaction of the membrane with phosphoric acid forms silicate phosphor, as a chemically bound proton carrier, in the membrane. Thus-formed silicate phosphor, nitrogen in the imidazole ring, and physically bound phosphoric acid act as proton carriers in the membrane. The physico-chemical and electrochemical properties of the membrane are investigated by various analytical tools. The phosphoric acid uptake and proton conductivity of the SDF-F/poly(VI-co-MPS)/PTFE membrane are higher than those of SDF-F/PVI/PTFE. The power densities of cells with SDF-F/poly(VI-co-MPS)/PTFE membranes at $0.6 \mathrm{~V}$ are 286,302 , and $320 \mathrm{~mW} \mathrm{~cm}^{-2}$ at 150,170 , and $190^{\circ} \mathrm{C}$, respectively. Overall, the SDFF/poly(VI-co-MPS)/PTFE membrane is one of the candidates for anhydrous HT-PEMFCs with enhanced mechanical strength and improved cell performance.
\end{abstract}

Key Words : High-temperature PEMFCs, Proton conducting membrane, Acid-doped membrane, Anhydrous condition

\section{Introduction}

A proton exchange membrane fuel cell (PEMFC) has been considered as one of the most promising clean energy production systems and as a suitable primary power source for transportation and stationary applications due to its major advantages such as high efficiency, high energy density, etc. ${ }^{1-6}$ The commercial application of PEMFC, however, has been limited by some issues such as cost, performance, and stability. ${ }^{1-6}$ Currently, the typical PEMFC uses perfluorosulfonic acid (PFSA) polymer membranes, for instance Nafion and its derivatives. ${ }^{1-6}$ Even though PFSA polymer membranes have demonstrated good performance and stability below $90{ }^{\circ} \mathrm{C}$, it still has several obstacles, such as high cost and low proton conductivity and poor performance under elevated temperature conditions. ${ }^{2,4-6}$

PEMFCs operated under high temperature and anhydrous conditions provide valuable advantages ${ }^{7}$ including high tolerance to impurities in the fuels, such as $\mathrm{CO}$ and hydrocarbon, reduction of the amount of noble metal catalyst on the electrode due to fast reaction kinetics, and construction of compact system without external humidifiers. Thus, the development of new PEM membranes for anhydrous, high temperature operation has been extensively studied. ${ }^{1,6,8,9}$ In our previous study, ${ }^{4}$ we proposed a novel membrane for high-temperature PEMFCs, $\mathrm{H}_{3} \mathrm{PO}_{4}$-doped sulfonated poly(fluorinated arylene ether)s (SDF-F)/poly $(N$-vinylimidazole) (PVI) membrane which is less expensive and more durable in phosphoric acid. The thermal stability and conductivity $\left(\sim 2.85 \times 10^{-2} \mathrm{~S} \mathrm{~cm}^{-1}\right)$ of the membrane were comparable to those of PBI. ${ }^{8}$ These PVI-series membranes, however, have poor mechanical properties after the reaction with phosphoric acid. $^{4}$

In the present study, we prepared SDF-F/poly[( $N$-vinylimidazole)-co-(3-methacryloxypropyl-trimethoxysilane)](poly(VI-co-MPS))/PTFE membrane which is doped with phosphoric acid to form silicate phosphor as a proton carrier. We used porous poly(tetrafluoroethylene) (PTFE) as a reinforcement material to improve its mechanical properties and tensile strength. The prepared membrane was characterized by various analytical tools. Single cell test for SDF-F/ poly(VI-co-MPS)/PTFE membrane was carried out at 150 , 170 , and $190{ }^{\circ} \mathrm{C}$ to examine the cell performance by measuring cell voltage degradation and phosphoric acid loss.

\section{Experimental}

Preparation of Blending Membrane and MEA. The synthesis of SDF-F was performed according to the procedure described in our previous publication. ${ }^{3}$ The prepared SDF-F (1.00 g) was dissolved in VI (4.23 g, $0.045 \mathrm{~mol})$ and MPS (1.22 g, $0.005 \mathrm{~mol})$ with azobisisobutyronitrile (AIBN) as an initiator for the polymerization of VI and MPS. The initial homogeneous mixture of SDF-F, VI, and MPS converts to a viscous solution during the polymerization process. The viscous solution was placed on a side of porous PTFE film ( $\sim 10 \mu \mathrm{m}$ thickness $)$, and then it was pressed at $100 \mathrm{kgf} \mathrm{cm}^{-2}$. Then, the other side of PTFE film was treated by the same procedure. Subsequently, it was hot-pressed $\left(40 \mathrm{kgf} \mathrm{cm}{ }^{-2}\right)$ at $130{ }^{\circ} \mathrm{C}$ for 1 hour. The prepared SDF-F/ 
poly(VI-co-MPS)/PTFE membrane was immersed into the phosphoric acid solution saturated by an excess amount of phosphorous pentoxide $\left(\mathrm{P}_{2} \mathrm{O}_{5}\right)$ at $100{ }^{\circ} \mathrm{C}$ for 48 hours. The prepared membrane was sandwiched in between two commercial Pt/C electrodes (E-TEK, Pt loading $=0.5 \mathrm{mg} \mathrm{cm}^{-2}$ ), and the membrane electrode assembly (MEA) was hotpressed $\left(40 \mathrm{kgf} \mathrm{cm}^{-2}\right)$ at $130{ }^{\circ} \mathrm{C}$ for 5 minutes. The detailed procedure was described elsewhere. ${ }^{4}$

Physical and Electrochemical Characterizations. The thermal stability of the membrane was investigated by thermogravimetric analysis (TGA, TA Instruments, SDT 2960). A ramping speed was $10^{\circ} \mathrm{C} \mathrm{min}^{-1}$ over the temperature range of $25-800{ }^{\circ} \mathrm{C}$ under a nitrogen atmosphere. The phosphoric acid uptake of the membranes was determined by measuring the difference of masses before and after immersing them into phosphoric acid. The chemical structure was identified by Fourier transform-infrared spectroscopy (FT-IR, Nicolet 380). The morphology and the elemental distribution of the prepared membrane were investigated by field emissionscanning electron microscopy (FE-SEM, Hitachi S-4300) and energy dispersive spectroscopy (EDS, Horiba EX-200) coupled with SEM. Electrochemical impedance spectroscopy (EIS) was carried out to measure the proton conductivity using a two probe technique ${ }^{3,4}$ with IM6 impedance analyzer (Zahner elektrik Co.). Impedance spectra were taken after an appropriate equilibrium period in the frequency range of 10 $\mathrm{mHz}$ to $10 \mathrm{kHz}$ with AC perturbation of $5 \mathrm{mV}$. The single cell tests were performed at 150,170 , and $190^{\circ} \mathrm{C}$ without any external humidification. The both electrodes were initially purged by dry nitrogen gas (flow rate $=80 \mathrm{~cm}^{3} \mathrm{~min}^{-1}$ ) for 12 hours. Then, the main experiments were performed with $\mathrm{H}_{2}$ and $\mathrm{O}_{2}$ (flow rate $=80 \mathrm{~cm}^{3} \mathrm{~min}^{-1}$ ) introduced into the anode and the cathode, respectively. To determine the amount of phosphoric acid loss, two stainless steel bottles were connected to gas outlets to collect the exhausted water during the experiment. The concentration of phosphoric acid in the exhausted water was analyzed by an ordinary $\mathrm{pH}$ meter.

\section{Results and Discussion}

Characterization. After the preparation of polymer membranes, the formation of copolymer was examined by infrared spectroscopy. Figure 1 shows the infrared spectra of poly MPS (PMPS), poly VI (PVI), poly(VI-co-MPS), and phosphoric acid-doped poly(VI-co-MPS). The obtained IR spectra of PMPS and PVI are corresponding to the previous publications. ${ }^{10-18}$ The IR spectrum of PMPS shows its characteristic vibrational features at $2841(\mathrm{C}-\mathrm{H}$ stretching in $\left.\mathrm{OCH}_{3}\right), 1729\left(\mathrm{C}=\mathrm{O}\right.$ stretching), $1460\left(\mathrm{CH}_{2}\right.$ bending $), 1085$ (Si-O-C asymmetric stretching), and $980 \mathrm{~cm}^{-1}$ (Si-O-Si bending). ${ }^{10-14}$ Interestingly, the IR spectrum of PMPS does not show the vibrational feature at $1637 \mathrm{~cm}^{-1}$, which is assigned to $\mathrm{C}=\mathrm{C}$ stretching, and the absence of monomeric $\mathrm{C}=\mathrm{C}$ stretching feature indicates the formation of polymerized MPS. For PVI, the vibrational features were observed at 1497 (C-C and $\mathrm{C}=\mathrm{N}$ (ring) stretching), 1227 (C-H (ring) inplane bending and $\mathrm{C}-\mathrm{N}$ (ring) stretching), and $915 \mathrm{~cm}^{-1}$

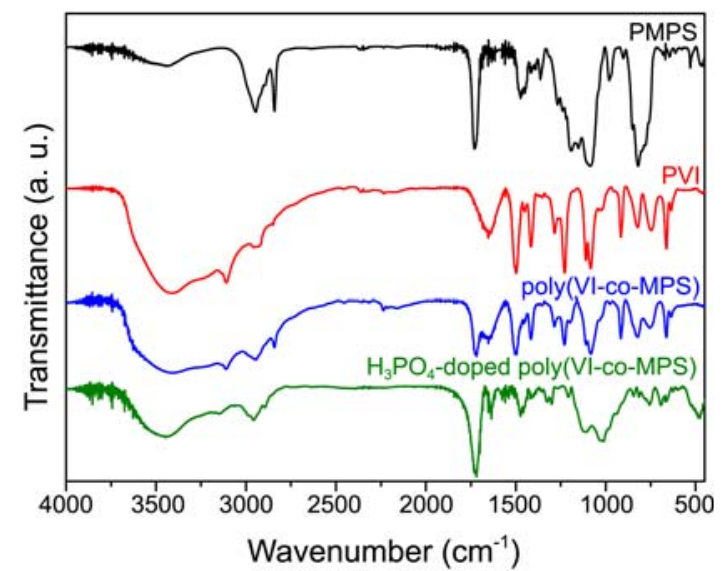

Figure 1. The FT-IR spectra for (a) MPS, (b) PVI and (c) poly(VIco-MPS), and (d) $\mathrm{H}_{3} \mathrm{PO}_{4}$-doped poly(VI-co-MPS).

(ring deformation) which are good agreement with previous literatures. ${ }^{15-18}$ The IR spectrum of poly(VI-co-MPS) shows the combined features of those of PMPS and PVI. However, the doping of phosphoric acid into poly(VI-co-MPS) causes significant change in IR spectrum. The frequency regions of $1250-800$ and $\sim 500 \mathrm{~cm}^{-1}$ which were assigned the main absorption bands of phosphoric acid and/or phosphates. ${ }^{8} 19$ Specifically, the broad absorption band at $\sim 1020 \mathrm{~cm}^{-1}$ is attributed to the presence of $\mathrm{Si}-\mathrm{O}-\mathrm{P}$ bond, and other one at $\sim 1120 \mathrm{~cm}^{-1}$ with a shoulder at $\sim 1170 \mathrm{~cm}^{-1}$ is originating from the asymmetric stretching of $\mathrm{PO}_{2}$ in $\mathrm{PO}_{4}$ group. ${ }^{5,19,20}$ The result of IR unambiguously shows that silicate phosphor is formed by the reaction between the phosphoric acid and the silane group in MPS.

For the operation of a high temperature PEMFC, the membranes should have a good thermal stability. Otherwise, the cell operation at high temperature may give damages to membranes that cause critical problems such as mass flow and voltage drop. The thermal stability of prepared membranes was investigated by TGA. Figure 2 shows TGA results of SDF-F/poly(VI-co-MPS) and SDF-F/poly(VI-co-MPS)/PTFE membranes. The weight loss below $100^{\circ} \mathrm{C}$ is mainly due to the loss of water. Then, the significant weight loss at 300-

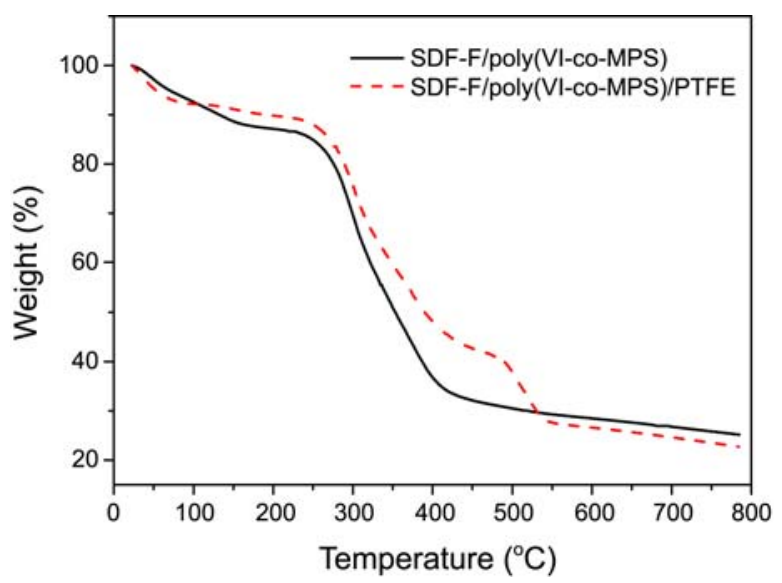

Figure 2. The TGA data of SDF-F/Poly(VI-co-MPS) blend membrane and SDF-F/Poly(VI-co-MPS)/PTFE blend membrane. 
$400{ }^{\circ} \mathrm{C}$ is attributed to the elimination of sulfonyl group in SDF-F ${ }^{4}$ and the degradation of VI rings ${ }^{17,18}$ and MPS. ${ }^{21,22}$ The thermal degradation temperature of PTFE is $\sim 500{ }^{\circ} \mathrm{C}$ corresponding to the previous result. ${ }^{4}$ Hence, the onset temperature for the degradation of SDF-F/poly(VI-co-MPS)/ PTFE membrane is higher than $250^{\circ} \mathrm{C}$. It is indicated that the prepared membrane demonstrates a good thermal stability enough to endure the high temperature operation (150-200 $\left.{ }^{\circ} \mathrm{C}\right)$.

The high proton conductivity can be achieved by the addition of proton carriers, such as a heteropoly acid. ${ }^{23,24}$ In this study, in order to obtain a good proton conductivity, SDF-F/poly(VI-co-MPS)/PTFE membrane was reacted with phosphoric acid since it acts as a proton carrier. ${ }^{25}$ As a result, through the reaction of the silane groups in MPS with phosphoric acid, the silicate phosphor was formed as shown in Figure 1. Thus-formed silicate phosphor and the physically adsorbed phosphoric acid affect the proton conductivity. Phosphoric acid uptake of SDF-F/poly(VI-co-MPS)/PTFE membrane was $561 \%$. On the other hand, the phosphoric acid uptake of SDF-F/PVI/PTFE membrane $\left(\sim 400 \%{ }^{4}\right)$ was lower than that of SDF-F/poly(VI-co-MPS)/PTFE.

The morphology of the membrane and distribution of $\mathrm{Si}$ and $\mathrm{P}$ in the membrane were investigated by SEM-EDS. Figure 3 shows SEM and EDS images for the cross-section of SDF-F/poly(VI-co-MPS)/PTFE membrane. Figures 3(a) and (c) show the morphologies of the membranes after drying at $120^{\circ} \mathrm{C}$ and after subsequent reaction with phosphoric acid for 48 hours, respectively. Prior to and after soaking the membrane in phosphoric acid, the thicknesses of the membrane were 66 and $172 \mu \mathrm{m}$, respectively. Figure 3(b) shows the distribution of $\mathrm{Si}$ of dried membrane shown in Figure 3(a), and it indicates that SDF-F/poly(VI-co-MPS) was perfectly impregnated in porous PTFE layer. Figure 3(d) shows P mapping image of phosphoric acid-doped membrane shown in Figure 3(c) which indicates the homogeneous distribution of $\mathrm{P}$ in the membrane after immersing the membrane into phosphoric acid. It is evident that the SDF-F and poly(VIco-MPS) was blended homogeneously and the phosphoric acid is doped well throughout the SDF-F/poly(VI-co-MPS)/ PTFE membrane.

Electrochemical Properties. The proton conductivity of the phosphoric acid-doped SDF-F/poly(VI-co-MPS)/PTFE membrane was investigated using electrochemical impedance spectroscopy in the frequency range of $10 \mathrm{mHz}-10 \mathrm{kHz}$ at $150-190{ }^{\circ} \mathrm{C}$. The proton conductivity was determined from the intercept of bulk resistance at high frequency in Nyquist plot. The detailed procedure is described elsewhere. ${ }^{4}$ At 150 ${ }^{\circ} \mathrm{C}$, the proton conductivity of the membrane is $6.01 \times 10^{-2} \mathrm{~S}$ $\mathrm{cm}^{-1}$ which is much higher than that of SDF-F/PVI/PTFE membrane $\left(2.20 \times 10^{-2} \mathrm{~S} \mathrm{~cm}^{-1}\right.$ at $\left.150{ }^{\circ} \mathrm{C}^{4}\right)$. The conductivities at 170 and $190{ }^{\circ} \mathrm{C}$ are $7.28 \times 10^{-2}$ and $7.68 \times 10^{-2} \mathrm{~S} \mathrm{~cm}^{-1}$,
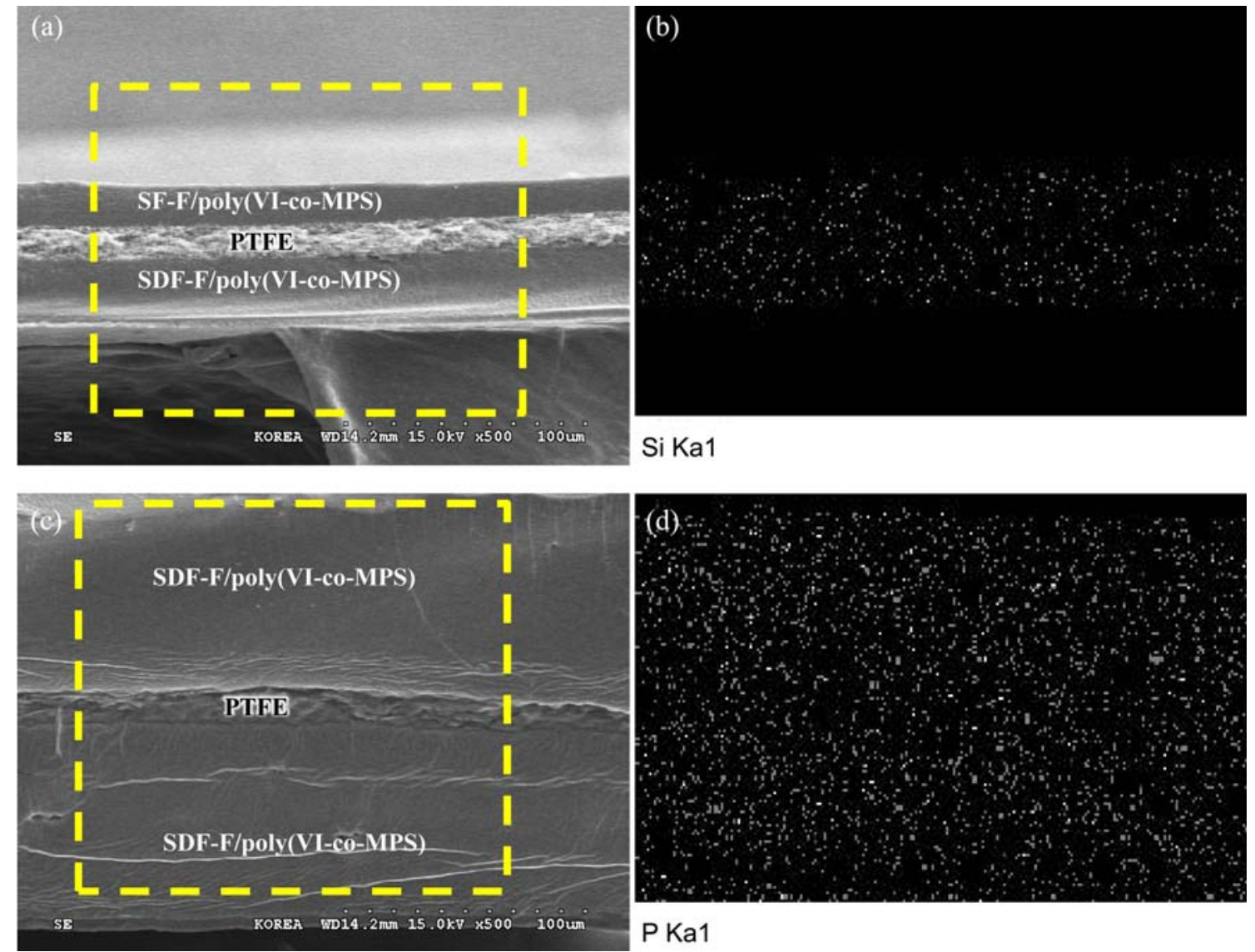

Figure 3. SEM images of the cross section of the SDF-F/Poly(VI-co-MPS)/PTFE blend membrane (a) before soaking, (b) Si mapping image of (a), SDF-F/Poly(VI-co-MPS)/PTFE blend membrane (c) after soaking in phosphoric acid, and (d) P mapping image of (c). 


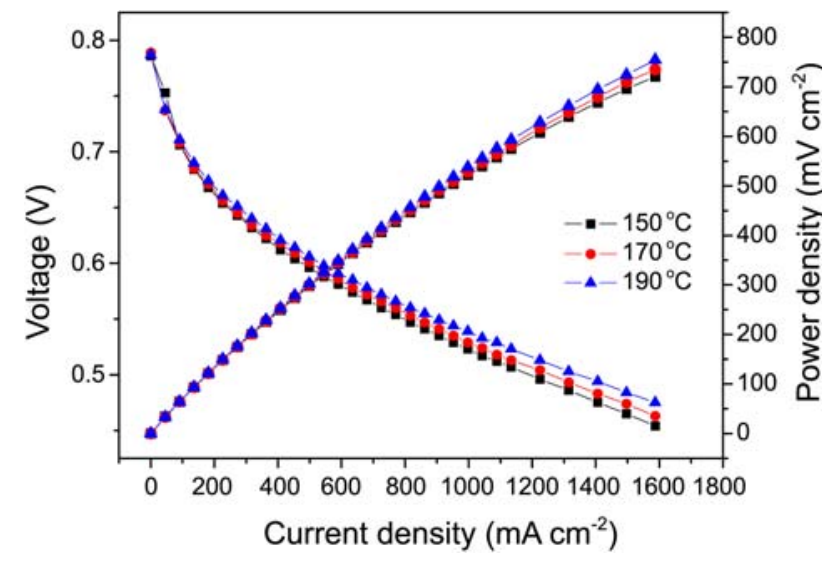

Figure 4. Current density vs. voltage and power density of the single cell operation with the SDF-F/Poly(VI-co-MPS)/PTFE blend membrane using hydrogen and oxygen gas (flow rate $80 \mathrm{~cm}^{3}$ $\min ^{-1}$ ) with no external humidification under ambient pressure at various temperature; $(\boldsymbol{\square}) 150^{\circ} \mathrm{C},(\bullet) 170{ }^{\circ} \mathrm{C}$, and $(\boldsymbol{\Delta}) 190^{\circ} \mathrm{C}$.

respectively. From the Arrhenius plot, the activation energy of proton conduction in this membrane is determined to $10.06 \mathrm{~kJ} / \mathrm{mol}$. This activation energy is lower than and/or comparable to that of phosphoric acid-doped PBI membrane. ${ }^{26}$ The better proton conductivity of phosphoric acid-doped SDF-F/poly(VI-co-MPS)/PTFE membrane than that of SDF-F/ PVI/PTFE is originating from the formation of silicate phosphor and high phosphoric acid uptake in the membrane because silicate phosphor and/or phosphoric acid can act as proton carriers. Moreover, due to the characteristics of aciddoped membrane that the conductivity proportionally increases with the doping level of phosphoric acid at constant temperature, phosphoric acid-doped SDF-F/poly(VI-co-MPS)/PTFE membrane with higher phosphoric acid uptake have better conductivity than SDF-F/PVI/PTFE at the same temperature. In this membrane, the high proton conductivity can be obtained with amphoteric acid as an active dopant because the amphoteric acids give associated anions which are able to act as both donors and acceptors in proton transfer. ${ }^{24,27}$

The performance of the membrane was investigated by measuring current density and voltage of a single cell. The single cell test was performed at 150,170 , and $190^{\circ} \mathrm{C}$ without any external humidification. Figure 4 represents the single cell performance as a function of operating temperature. The current density at constant voltage increases with an increase in the temperature. This is a typical phenomenon of an aciddoped membrane since the rate of reaction on the electrode and the proton conductivity of membrane are enhanced as the cell temperature increases. ${ }^{28,29}$ The power densities of SDF-F/poly(VI-co-MPS)/PTFE membrane at $0.60 \mathrm{~V}$ were 286,302 , and $320 \mathrm{~mW} \mathrm{~cm}^{-2}$ at 150,170 , and $190^{\circ} \mathrm{C}$, respectively. This power density of SDF-F/poly(VI-co-MPS)/PTFE membrane is higher than that of SDF-F/PVI/PTFE membrane $\left(263.5 \mathrm{~mW} \mathrm{~cm}^{-2}\right.$ at the temperature of $\left.150{ }^{\circ} \mathrm{C}^{4}\right)$.

The durability of the SDF-F/poly(VI-co-MPS)/PTFE membrane was examined at $190^{\circ} \mathrm{C}$ under the same condition as the single cell test, and a control experiment was performed with SDF-F/PVI/PTFE membrane. Figure 5 shows the cell

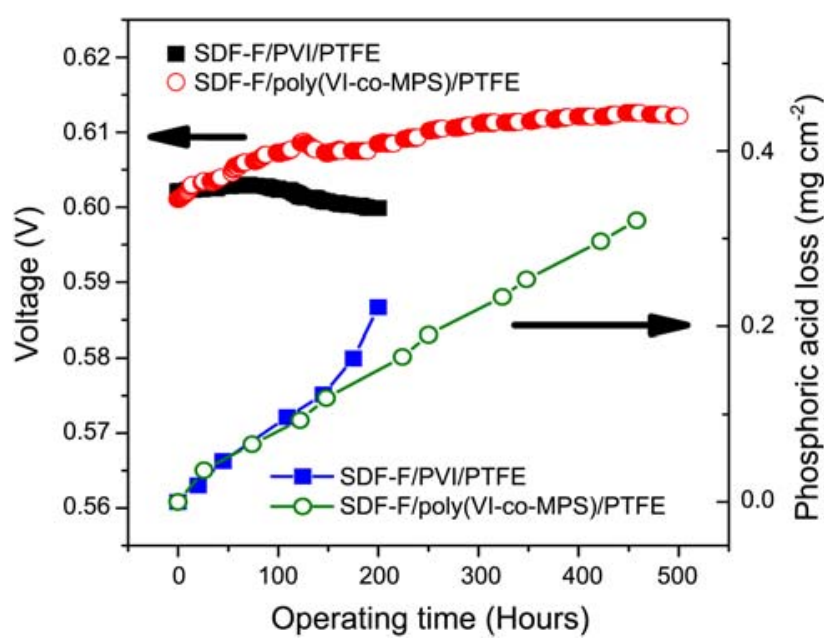

Figure 5. Voltage and phosphoric acid loss during long-term operation for SDF-F/PVI/PTFE and SDF-F/Poly(VI-co-MPS)/ PTFE blend membrane fuel cell operated at $190^{\circ} \mathrm{C}$ with hydrogen and oxygen gas under steady-state operating conditions.

voltage and the amount of phosphoric acid loss from the membrane as a function of operating time. The cell voltage and phosphoric acid loss of SDF-F/PVI/PTFE and SDF-F/ poly(VI-co-MPS)/PTFE membranes were monitored at the fixed current densities of 470 and $533 \mathrm{~mA} \mathrm{~cm}^{-2}$, respectively. For the SDF-F/PVI/PTFE membrane, even though the voltage drop was not observed for 0-70 hours, we observed the reduction of cell voltage after 70 hours. The rates of voltage drop and phosphoric acid loss were $11 \mu \mathrm{V} \mathrm{h}^{-1}$ and $1.11 \times 10^{-3}$ $\mathrm{mg} \mathrm{cm}{ }^{-2} \mathrm{~h}^{-1}$, respectively. On the other hand, for SDF-F/ poly(VI-co-MPS)/PTFE membrane, the voltage drop was not observed for 500 hours. Interestingly, the voltage increases from 0.601 to $0.612 \mathrm{~V}$ during the durability test, even if the loss of phosphoric acid from the membrane was observed. The rate of phosphoric acid loss was $7.4 \times 10^{-4} \mathrm{mg} \mathrm{cm}^{-2} \mathrm{~h}^{-1}$ which is much lower than that of SDF-F/PVI/PTFE membrane. The phosphoric acid loss is the main problem in degradation of $\mathrm{H}_{3} \mathrm{PO}_{4}$-doped polymer membrane. ${ }^{30}$ Interestingly, even though the phosphoric acid was continuously leaked from SDF-F/poly(VI-co-MPS)/PTFE membrane, the voltage drop was not observed in the present study. Because the membrane initially contains excess amount of phosphoric acid which is the weakly (physically) bound phosphoric acid, the initial loss rate of phosphoric acid measured by $\mathrm{pH}$ of the exhausted water should be higher than the average value. It is reported that the concentration of phosphoric acid in the exhausted water for the acid-doped PBI membrane ${ }^{31}$ was initially high. After a certain time, however, the loss rate decreases and is much lower than initial value. ${ }^{31}$ Moreover, due to the reduction of the concentration of phosphoric acid in the membrane with increasing operating time, the flux of phosphoric acid leaked from the membrane should also decrease according to Fick's law. In fact, considering the formation of carbonates in the exhausted water from atmospheric $\mathrm{CO}_{2}$, the initial rate of phosphoric acid loss $\left(7.4 \times 10^{-4} \mathrm{mg} \mathrm{cm}^{-2} \mathrm{~h}^{-1}\right)$ is overestimated. Therefore, the reaction of SDF-F/poly(VI-coMPS)/PTFE membrane with phosphoric acid forms silicate 
phosphor, as a chemically bound proton carrier, in the membrane. The existence of silicate phosphor in the membrane increases its proton conductivity and improves the cell performance.

\section{Conclusion}

We successfully prepared phosphoric acid-doped sulfonated poly(fluorinated arylene ether)s (SDF-F)/poly[ $(N$-vinylimidazole)-co-(3-methacryloxypropyl-trimethoxysilane)] (poly(VI-co-MPS))/PTFE as a polymer electrolyte membrane for high temperature PEMFC and investigated the membrane with various analytical tools. The chemical structure of prepared membrane was confirmed by FT-IR. SDF-F/poly(VIco-MPS)/PTFE membrane shows a better thermal stability with respect to PVI-series membranes and homogeneous distribution of $\mathrm{Si}$ and $\mathrm{P}$ after the reaction with phosphoric acid. The membrane has higher phosphoric acid uptake $(561 \%)$ and proton conductivity $\left(6.01 \times 10^{-2}-7.68 \times 10^{-2} \mathrm{~S}\right.$ $\mathrm{cm}^{-1}$ at $150-190^{\circ} \mathrm{C}$ ) with respect to SDF-F/PVI/PTFE. For the single cell test (cell voltage $=0.6 \mathrm{~V}$ ), power density was $320 \mathrm{~mW} \mathrm{~cm}^{-2}$ at $190{ }^{\circ} \mathrm{C}$, and it shows stable performances. For steady-state fuel cell operation at $190{ }^{\circ} \mathrm{C}$, the phosphoric acid loss rate from the SDF-F/poly(VI-co-MPS)/PTFE blend membranes was $7.4 \times 10^{-4} \mathrm{mg} \mathrm{cm}^{-2} \mathrm{~h}^{-1}$. These experimental results show that the SDF-F/poly(VI-co-MPS)/PTFE membranes has a good proton conductivity, stability, and high cell performance for high temperature operation. The SDF-F/poly(VI-co-MPS)/PTFE blend membranes can be a promising as the proton conducting electrolyte for the PEMFCs working at the high temperatures $\left(150-190^{\circ} \mathrm{C}\right)$.

Acknowledgments. This work was also supported by the Sungshin Women's University Research Grant of 2010.

\section{References}

1. Wang, J. T.; Savinell, R. F.; Wainright, J.; Litt, M.; Yu, H. Electrochim. Acta 1996, 41, 193-197.

2. Savadogo, O. J. Power Sources 2004, 127, 135-161.

3. Lee, H. C.; Hong, H. S.; Kim, Y. M.; Choi, S. H.; Hong, M. Z.; Lee, H. S.; Kim, K. Electrochim. Acta 2004, 49, 2315-2323.

4. Choi, D. H.; Lee, J.; Kwon, O.; Kim, J.-Y.; Kim, K. J. Power
Sources 2008, 178, 677-682.

5. Huang, S.-J.; Lee, H.-K.; Kang, W.-H. Bull. Korean Chem. Soc. 2005, 26, 241

6. Asensio, J. A.; Borros, S.; Gomez-Romero, P. J. Membrane Sci. 2004, 241, 89-93.

7. Li, Q. F.; He, R. H.; Jensen, J. O.; Bjerrum, N. J. Chem. Mat. 2003, 15, 4896-4915.

8. Asensio, J. A.; Borro, S.; Gomez-Romero, P. J. Electrochem. Soc. 2004, 151, A304-A310.

9. Mecerreyes, D.; Grande, H.; Miguel, O.; Ochoteco, E.; Marcilla, R.; Cantero, I. Chem. Mat. 2004, 16, 604-607.

10. Lu, H. B.; Hu, Y.; Gu, M. H.; Tang, S. C.; Lu, H. M.; Meng, X. K. Surf. Coat. Tech. 2009, 204, 91-98.

11. Pantoja, M.; Diaz-Benito, B.; Velasco, F.; Abenojar, J.; del Real, J. C. Appl. Surf. Sci. 2009, 255, 6386-6390.

12. Siddiquey, I. A.; Ukaji, E.; Furusawa, T.; Sato, M.; Suzuki, N. Mater. Chem. Phys. 2007, 105, 162-168.

13. Chang, T. C.; Wang, Y. T.; Hong, Y. S.; Chen, H. B.; Yang, J. C. Polym. Degrad. Stabil. 2000, 69, 317-322.

14. Lu, X.; Xin, Z. Colloid Polym. Sci. 2007, 285, 599-604.

15. Küęükyavuz, Z.; Küçükyavuz, S.; Abbasnejad, N. Polymer 1996, 37, 3215-3218.

16. Lippert, J. L.; Robertson, J. A.; Havens, J. R.; Tan, J. S. Macromolecules 2002, 18, 63-67.

17. Pekel, N.; Olgun, G.e. Polym. Int. 2002, 51, 1404-1410.

18. Pekel, N.; Olgun, G.e. Polym. Int. 2008, 57, 637-643.

19. Glipa, X.; Bonnet, B.; Mula, B.; Jones, D. J.; Rozière, J. J. Mater. Chem. 1999, 9, 3045-3049.

20. Matsuda, A.; Kanzaki, T.; Kotani, Y.; Tatsumisago, M.; Minami, T. Solid State Ionics 2001, 139, 113-119.

21. Abe, Y.; Honda, Y.; Gunji, T. Appl. Organomet. Chem. 1998, 12, 749-753.

22. Chang, T. C.; Yeh, T. F.; Yang, C. W.; Hong, Y. S.; Wu, T. R. Polymer 2001, 42, 8565-8570.

23. Gómez-Romero, P.; Asensio, J. A.; Borrós, S. Electrochim. Acta 2005, 50, 4715-4720.

24. He, R.; Li, Q.; Xiao, G.; Bjerrum, N. J. J. Membrane Sci. 2003, 226, 169-184.

25. Matsuda, A.; Kanzaki, T.; Tadanaga, K.; Tatsumisago, M.; Minami, T. Electrochim. Acta 2001, 47, 939-944.

26. Ma, Y. L.; Wainright, J. S.; Litt, M. H.; Savinell, R. F. J. Electrochem. Soc. 2004, 151, A8-A16.

27. Bouchet, R.; Siebert, E. Solid State Ionics 1999, 118, 287-299.

28. Xie, Z.; Holdcroft, S. Journal of Electroanalytical Chemistry 2004, 568, 247-260

29. Qingfeng, L.; Hjuler, H. A.; Bjerrum, N. J. J. Appl. Electrochem. 2001, 31, 773-779.

30. Zhai, Y. F.; Zhang, H. M.; Liu, G.; Hu, J. W.; Yi, B. L. J. Electrochem. Soc. 2007, 154, B72-B76.

31. Yu, S.; Xiao, L.; Benicewicz, B. C. Fuel Cells 2008, 8, 165-174. 